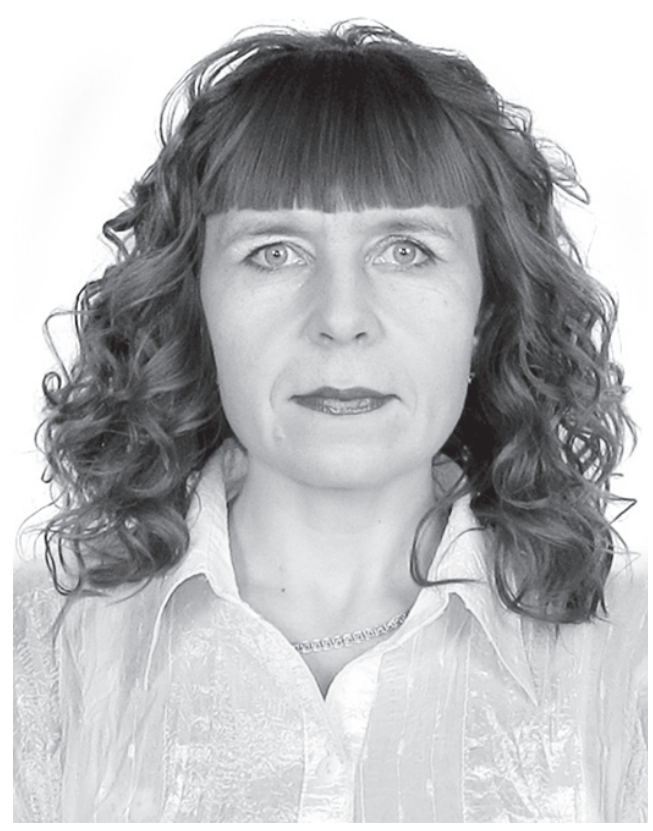

УДК: 351:37.013

DOI: https://doi.org/10.32689/26172224-2019-17-2-136-144

\section{Лебєдєва Надія Анатолївна,} аспірант кафедри публічного адміністру вання, Міжрегіональна Академія управління персоналом, 03039, Київ, вул. Фрометівська, 2, тел.: +38 (063) 48152 95, e-mail:vsesvit894@ukr.net

ORCID: 0000-0003-4095-2631

Лебедева Надежда Анатольевна, аспирант кафедры публичного администрирования, Межрегиональная Академия управления персоналом, 03039, Киев, ул. Фрометовская, 2, тел.: +38 (063) 481 52 95, e-mail: vsesvit894@ukr.net ORCID: 0000-0003-4095-2631

\section{Lebedeva Nadezhda Anatolievna,} post-graduate student of the Department of Public Administration, Interregional Academy of Personnel Management, 03039, Kyiv, Str. Frometivska, 2, tel.: +38 (063) 48152 95, e-mail: vsesvit894@ukr.net

ORCID: 0000-0003-4095-2631

\title{
КОМУНІКАЦІЯ СУСПІЛЬСТВА І ОРГАНІВ МІСЦЕВОГО САМОВРЯДУВАННЯ В КОНТЕКСТІ ДІЯЛЬНОСТІ ГРОМАДСЬКИХ ОРГАНІЗАЦІЙ
}

Анотація. Розглянуто комунікаційний процес певних соціальних груп i органів місцевого самоврядування в контексті діяльності громадської організації, а також нову редакцію Закону України “Про громадські об'єднання”, який сприятиме вдосконаленню громадянського суспільства.

Висвітлено діяльність громадської організації м. Херсона в контексті комунікації суспільства й органів місцевого самоврядування, спираючись на дослідження таких українських науковців, як Т. В. Журенок, В. К. Колпаков, В. М. Менджул, С. М. Грудницька, Т. П. Руцинська, О. В. Титова та ін.

Громадські організації останнім часом все частіше виступають організаторами різноманітних заходів, проектів щодо вирішення конкретних суспільно значущих питань. Таке явище цілком природно, оскільки однією 3 найбільш правових форм допомоги громадянам, конкретним людям, які потребують допомоги у вирішенні складних спільних проблем, є існування об’єднань громадян. Громадські організації є ефективним інструментом ознайомлення, допомоги, комунікації, соціального ефекту. 
Виходячи із загального підходу порівняльного аналізу визначення поняття “комунікації, складеного відомим українським науковцем Д. В. Кісловим, проаналізовано діяльність громадської організації з органами місцевого самоврядування у досягненні певних соціально значущих завдань.

Наголошено, що практична діяльність громадських організацій вимагає ширшого наукового спостереження і вивчення комунікації різних соціальних груп і державного управління, та розроблення пропозицій щодо вдосконалення комунікаційного процесу із застосуванням підходів державного управління.

Ключові слова: підхід, державне управління, громадські організації, фонд інвалідів, Чорнобиль.

\section{КОММУНИКАЦИЯ ОБЩЕСТВА И ОРГАНОВ МЕСТНОГО САМОУПРАВЛЕНИЯ В КОНТЕКСТЕ ДЕЯТЕЛЬНОСТИ ОБЩЕСТВЕННЫХ ОРГАНИЗАЦИЙ}

Аннотация. Рассмотрены коммуникационный процесс определенных социальных групп и органов местного самоуправления в контексте деятельности общественной организации, а также новая редакция Закона Украины “Об общественных объединениях", который способствует совершенствованию гражданского общества.

Освещена деятельность общественной организации г. Херсона в контексте коммуникации общества и органов местного самоуправления, основываясь на исследованиях таких украинских научных деятелей, как Т. В. Журенок, В. К. Колпаков, М. Менджул, С. М. Грудницкая, Т. П. Руцинская, О. В. Титова и др.

Общественные организации в последнее время все чаще выступают в качестве организаторов различных мероприятий, проектов в решении конкретных общественно важных вопросов. Такое явление вполне естественно, поскольку является одной из самых действенных правовых форм помощи гражданам, конкретным людям, нуждающимся в помощи в решении сложных общих проблем. Общественные организации являются эффективным инструментом ознакомления, помощи, коммуникации, социального эффекта.

Исходя из общего подхода сравнительного анализа определения понятия “коммуникации”, составленного известным украинским ученым Д. В. Кисловым, проанализирована деятельность общественной организации с органами местного самоуправления в достижении определенных социально значимых задач.

Определено, что практическая деятельность общественных организаций требует более широкого поля научного наблюдения и изучения коммуникации различных социальных групп и государственного управления, а также разработки предложений по совершенствованию коммуникационного процесса с применением подходов государственного управления. 
Ключевые слова: подход, государственное управление, общественные организации, фонд инвалидов, Чернобыль.

\section{COMMUNICATION OF SOCIETY AND LOCAL GOVERNMENT BODIES IN THE CONTEXT OF PUBLIC ORGANIZATIONS' ACTIVITIES}

Abstract. This article is dedicated to the communication process of certain social groups and local governments in the context of the activities of a public organization. Public associations have repeatedly attracted the attention of Ukrainian scientists such as T. V. Zhurenok, V. K. Kolpakov, M. Menjul, S. M.Grudnitskaya, T. P. Rutsinskaya, O. V. Titova, and others. The new edition of the Law of Ukraine On Public Associations contributes to the improvement of civil society.

The purpose of the article to consider the activities of the public organization of the city of Kherson in the context of communication of society and local governments based on the analysis of current legislation and research of modern Ukrainian scientists,

Recently, public organizations have increasingly been acting as organizers of various events and projects to address specific socially significant issues. Such a phenomenon is quite natural, since it is one of the most effective legal forms of assistance to citizens, specific people who need help in solving complex common problems. Public organizations are some effective tool for dating, help, communication, social effect.

Based on the general approach of a comparative analysis of the definition of the concept of "communication" compiled by a well-known Ukrainian scientist D. V. Kislov, the activity of a public organization with local governments in the achievement of certain socially significant tasks has been analyzed.

It was concluded that the practical activity of public organizations is a wide field for scientific observation and study of communication of various social groups and state administration, which requires the development of proposals for improving the communication process using the approaches of state administration.

Keywords: approach, public administration, public organizations, fund for persons with disabilities, Chernobyl.

Постановка проблеми. Громадські організації останнім часом все частіше виступають у якості організаторів різноманітних заходів, проектів щодо вирішення конкретних суспільно значущих питань. Таке явище цілком природно, оскільки однією з найбільш правових форм допомоги громадянам, конкретним людям, які потребують допомоги у вирішенні складних спільних проблем, є існування об'єднань громадян. Громадські організації являють собою ефективний інструмент 
знайомства, допомоги, комунікації, соціального ефекту. "Традиційним сектором у структурі громадянського суспільства виступає недержавний або комерційний сектор. Недержавний сектор називають ще неприбутковим, волонтерським i, нарешті, третім сектором або ж громадянським суспільством у вузькому розумінні. Третій сектор утворюють різноманітні недержавні інституції: об'єднання, асоціації, рухи, благодійні установи, органи самоорганізації населення" [1, с. 356]. Обмін досвідом з вирішення питань, що $є$ актуальними визначеному колу громадян, обговорення рішень і шляхів їхнього втілення у життя, отримання консультацій і пошук фахівців в органах місцевого самоврядування все це $є$ діяльністю громадських об'єднань. Отже, у контексті досліджень з комунікації діяльність громадських об'єднань з органами державного управління не втрачає своєї актуальності.

Аналіз останніх досліджень i публікацій. Громадські об'єднання неодноразово привертали увагу українських науковців. Так, Т. В. Журенок розглянуто класифікації громадських об'єднань, наведено приклади поділу неурядових організацій, які запропоновані як вітчизняними, так і зарубіжними дослідниками, або витікають з чинного національного законодавства [1]. Поняттям і видам громадських організацій присвячували свої наукові розвідки такі вчені, як В. К. Колпаков [2], В. М. Менджул [3] В. Гурлов [4]. Проблеми розвитку законодавства України про громадські організації у господарсько-правовому ас- пекті розглядали С. М. Грудницька [5] i Т. П. Руцинська [6]. Окремим аспектам статусу громадських об'єднань, які безпосередньо здійснюють підприємницьку діяльність, присвячено наукову статтю О. В. Титової [7]. Нова редакція Закону України “Про громадські об'єднання”, вважаємо, є достатньо добре виписаним законом, що сприяє вдосконаленню громадянського суспільства [8].

Мета статті - на основі аналізу чинного законодавства та досліджень сучасних українських науковців розглянуто діяльність громадської організації м. Херсона в контексті комунікації суспільства і органів місцевого самоврядування.

Виклад основного матеріалу. На думку відомого українського вченого, доктора наук з державного управління, професора Е. О. Романенка, найактуальнішими 3 наукових питань є ті, “які стосуються дослідження специфіки поширення комунікативних процесів на розвиток суспільства, що, в кінцевому підсумку, призводить до трансформації різних ціннісних систем, на яких базуються відповідні ідеологічні доктрини щодо формування державної політики” [9, с. 22]. У такому контексті “особливого значення набуває дослідження проблемних питань в сфері з'ясування місця і ролі комунікації в розвитку сучасного суспільства. Тобто, тут принциповим питанням є дослідити наскільки комунікація як соціальний феномен сприяе розгортанню соціокультурної динаміки суспільства, як трансформується суспільна свідомість в результаті розвитку відповідних комунікативних процесів. Розгляд даного питання безпосеред- 
ньо пов'язується з аналізом розвитку суспільної комунікації, більш того, найціннішим питанням $є$ розвиток суспільної комунікації, яка сприяе формуванню нової моделі соціальної організації - комунікативного суспільства" [9, с. 22-23]. На думку автора цієї наукової статті, розвиток суспільної комунікації відбувається за участю діяльності громадських організацій.

Якщо розглянути діяльність Херсонської обласної громадської організації "Фонд інвалідів Чорнобиля плюс”, то можемо спостерігати конкретний приклад такої комунікації. За словами голови Фонду Л. Лахнеко, проблема інвалідності гостро стоїть у багатьох країнах світу. Щоб привернути увагу до цієї проблеми, Організація Об'єднаних Націй затвердила 3 грудня - Днем інвалідів. У свою чергу, “Фонд інвалідів Чорнобиля плюс" приділяє значну увагу більшій соціалізації дітей у громаді. Коли здорові діти спілкуються з ровесниками, які мають певні проблеми зі здоров'ям, вони ставляться до них $з$ особливою любов'ю, розуміють, що не все може бути в цьому світі повноцінним, існують також і певні відхилення [10].

Вже четвертий рік поспіль громадська організація "Фонд інвалідів Чорнобиля плюс” проводить благодійний концерт "Свято добра" для дітей з особливими потребами. Мета концерту - це формування у дітей загальнолюдських цінностей: доброти, милосердя, толерантності, співпереживання. Діти показують свої нові творчі роботи, створюють справжнє Свято добра. Все відбувається на великій професійній сцені “Палацу молоді і студентів" у м. Херсоні. I дорослі, і діти отримують заряд бадьорості та гарного настрою. "Свято добра для того, щоб ми стали добрішими. Люди сперечаються, але в результаті приходять до того, що доброта потрібна кожному з нас. Що це подібно до садів, які цвітуть у наших душах. Добрі слова, думки - це квіти, добрі справи плоди в житті, кожен живе по-своєму. У кожному з нас є сонце. Даруйте своє тепло, доброту. Красна людина, коли вона добра. Не бійтеся робити добро!" [11].

Виступ на великій сцені - це значуща подія для будь-якої людини, адже треба добре підготуватися i вийти до величезного залу, приховуючи в глибині душі власне хвилювання, але яке потім почуття Перемоги над собою і впевненості в успіху. Особливо це важливо для дітей, на яких багато людей (будемо чесними) в силу економічної і політичної кризи не звертають уваги як на гідних членів суспільства. На сцені діти демонструють свою красу, вміння радіти життю, свій талант. Мова жестів, танець під ритмічну музику справляють величезне враження на присутніх в залі глядачів. Слова подяки звучать на адресу Людмили Іванівни Лохнеко, яка надає таку можливість для підняття самооцінки і розвитку таланту дітей з особливими потребами. Хореографічні композиції, представлені дітьми Херсонського обласного центру соціальної реабілітації дітей-інвалідів, виконання пісні на сурдомові, що супроводжується дивним по ритміці танцем дівчат, які не чують звуки оточуючого світу - все це на- 
повнює зал добрими посмішками, бажанням аплодувати [11].

Свято добра завжди відвідують, підтримують його проведення і заходи подібні до нього, представники міської влади. Так, наприклад, у 2018 р. було проведено такі заходи, як: 26 квітня - День чорнобильців в “Палаці молоді і студентів"; 5 вересня - гуманітарна акція у клубі “Miленіум”, де 250 людей з особливими потребами отримали подарунки i гуманітарну допомогу; 8 листопада - Свято добра; 3 грудня - Свято добра до дня інвалідів із врученням подарунків кожній дитині; 14 грудня - день ліквідатора аварії на ЧАЕС в Обласному госпіталі ветеранів війни, якому Фонд допоміг у придбанні меблів; 29 грудня - Новорічна ялинка з подарунками у кіноконцертній залі “Ювілейний” для дітей $з$ багатодітних, малозабезпечених сімей і дітей-інвалідів; 4 січня 2019 р. було вручено новорічні подарунки маленьким пацієнтам Дитячої обласної клінічної лікарні.

За словами директора Херсонського обласного центру соціальної реабілітації дітей-інвалідів Лідії Нiкішиної, дана громадська організація - це “люди, яким абсолютно не байдужа проблема дітей-інвалідів, проблема сімей, де є діти з особливими потребами”. Дітки показали свої таланти, свою творчість і ми побачили, що ці діти - вони такі як всі. Але це велика робота, яка проведена колективом центру, педагогами, обслуговуючим персоналом тому, що діти знаходяться у центрі тимчасово, їм продовжувати своє життя, соціалізуватися до суспільства: вони підуть до дитячих садочків, до загальноосвітніх шкіл, вони будуть жити у сім'ях, спілкуватися зі своїми рідними, близькими людьми, сусідами. Тому наше основне завдання - ї соціалізувати. У центрі створюються всі умови для того, щоб дітям було добре, щоб навчальний процес був спрямований правильно, і сьогодні завдяки благодійному “Фонду інвалідів Чорнобиля плюс” у нас обладнано 3 аудиторії з підготовки дітей до школи. Це, перш за все, кожній дитині надано парти, бо кожна дитина повинна мати індивідуальне місце, обладнані спальні, обладнані їдальні для того, щоб діти відчували себе комфортно" [10].

Виходячи із загального підходу порівняльного аналізу визначення поняття “комунікації, складеного відомим українським науковцем Д. В. Кісловим [9, с. 77], громадські організації здійснюють людську взаємодію в світі, а філософсько-практичний підхід дає нам ознаку конструктивної взаємодії особистостей, соціальних груп “чорнобильців” і “інвалідів”, що розгортається на грунті порозуміння і толерантності.

3 точки зору соціологічного підходу, в ході комунікації соціальних груп “чорнобильців" та "інвалідів" 3 міською владою здійснюється механізм існування і розвитку людських відносин - усі символи розуму разом із засобами їх передачі в просторі, що збережені у часі, спілкування - полягають у запрошенні на заходи, що проводяться громадськими організаціями, являють собою передачу інформації людиною людині у межах соціально-інформаційного підходу державного управління [9, c. 77]. Інформаційно-орієнтований 
загальний підхід реалізується процесами перекодування вербально у невербальну і невербальної у вербальну сфери, що демонструють концертні номери дітей-інвалідів по слуху, коли дітлахи танцюють і співають на сцені “Палацу молоді і студентів”, і глядачі навіть не здогадуються про проблему зі здоров'ям цих дітей. Діти показують, що вони також талановиті та успішні подібно до їхніх здорових однолітків.

Концерти, що проводяться Херсонською обласною громадською організацією "Фонд інвалідів Чорнобиля плюс”, з точки зору інформаційно-світоглядного підходу, $\epsilon$ процесом спілкування і передачі інформації, засобом формування світогляду і громадської думки широких мас милосердного ставлення до ближнього, толерантності й добра, бажанням допомогти. Це процес передачі інформації про буття людей, можливості яких обмежені хворобою.

Діяльність цієї громадської організації може бути описана з точки зору економічно-орієнтованого підходу в результаті процесу передачі інформації між двома сторонами: виробника й аудиторії, коли, наприклад, кондитери створюють з благодійною метою торт для дітей-інвалідів.

Якщо взяти до уваги управлінсько-орієнтований змістовно-соціальний підхід [9, с. 77-78], організація “Фонд інвалідів Чорнобиля плюс” реалізує своєю діяльністю змістовний аспект соціальної взаємодії місцевих органів влади та соціальної групи людей 3 обмеженими можливостями як соціальних об'єктів шляхом безпосереднього спілкування і обміну інформацією. Об’єднуючий підхід реалізується в акті спілкування, зв’язку між індивідуумами, заснованому на взаєморозумінні, повідомленні інформації від людей з обмеженими можливостями про їні потреби органам місцевої влади. "В умовах становлення і формування інформаційного суспільства соціально-політична спрямованість поняття “комунікація” стає все більш актуальною для розуміння його як універсальної категорії трансформованого соціуму" [9, с. 78].

Висновки i пропозиціі. Отже, практична діяльність громадських організацій являє собою широке поле для наукового спостереження i вивчення комунікації різних соціальних груп і державного управління та потребує розробки пропозицій щодо вдосконалення комунікаційного процесу із застосуванням підходів державного управління.

\section{СПИСОК ВИКОРИСТАНИХ ДЖЕРЕЛ}

1. ЖуренокТ.В.Правовийстатуставиди громадських об'єднань [Електроний ресурс] / Т. В. Журенок // Форум права. - 2012. - № 4. C. 356-361. - Режим доступу: http: // arhive.nbuv.gov.ua/ e-journals/FP/Downloads/FP/20124/12gtvvgo.pdf

2. Курс адміністративного права України: підручник / [Колпаков В. К. та ін., за ред. В. В. Коваленка] / Нац. академія внутрішніх справ. - К.: Юрінком Інтер, 2012. - 805 с.

3. Менджул В. М. Види громадських організацій в Україні / В. М. Менджул // Часопис Київського ун-ту права. - 2009. - № 1. - С. 184-188. 
4. Гурлов В. Форми та види громадських спілок та об'єднань [Електронний ресурс]. - Режим доступу: https://pravdop.com/ua/ publications / kommentari zakonodatelstva/formi-i-vidiobshestvennih-obedineniy

5. Груднищька С. М., Рущинська Т. П. Проблеми розвитку законодавства України про громадські організації: господарсько-правовий аналіз [Електроний ресурс] / С. М. Грудницька, Т. П. Руцинська // Форум права. - 2014. - № 4. - С. 99-106. Режим доступу: http: nbuv.gov.ua/jpdf/FP_index.htm_2014_4_20.pdf

6. Рущинська T. П. Удосконалення законодавства про громадські організації у світлі Євроінтеграції: господарсько-правовий аналіз / Т. П. Руцинська // Наук. вісн. Ужгородського нац. ун-ту. - 2015. - Вип. 31. - T. 2. - C. 60-64.

7. Титова О. В. Окремі аспекти статусу громадських об'єднань, які безпосередньо здійснюють підприємницьку діяльність [Електроний ресурс] / О. В. Титова // Форум права. 2016. - № 3. - С. 250-254. - Режим доступу: http: nbuv.gov.ua/j-pdf/FP_ index.htm_2016_3_46.pdf

8. Закон України "Про громадські об'єднання” [Електронний ресурс] // Офіц. сайт Верховної Ради України. - Режим доступу : https://zakon. rada.gov.ua/laws/show/4572-17

9. Кислов Д. В., Романенко Е. А., Чаплай И. В. Маркетинговые коммуникации в публичном администрировании: монография / Д. В. Кислов, Е. А. Романенко, И. В. Чаплай. - LAP Lambert Academic Publishing, 2018. - 419 c.

10. С любовью к детям [Электронный pecypc]. - Режим доступа: https:// youtu.be/4aWhFME-jgQ

11. День добра [Электронный peсурс]. - Режим доступа: https:// w w w . y o u t u b e.co m/ watch $? \mathrm{v}=\mathrm{NvbID}$ lbioe $4 \& \mathrm{t}=296 \mathrm{~s}$

\section{REFERENCES}

1. Zhurenok T. V. (2012), "Legal status and types of public associations", Forum prava, [Online], vol. 4, p. 356361, available at: http: // arhive.nbuv. gov.ua/ e-journals/FP/Downloads/ FP/2012-4/12gtvvgo.pdf (Accessed 10 Jen 2019).

2. Kolpakov V. K., Kovalenko V. V. (2012), Kurs administratyvnogo prava Ukrayiny: [Tekst] pidruchnyk [Course of administrative law of Ukraine], Nacional'na akademiya vnutrishnix sprav, Yurinkom Inter, Kyiv, Ukraine.

3. Mendzhul V. M. (2009), "Types of public organizations in Ukraine", Chasopys Kyivs'kogo universytetu prava, vol. 1, p. 184-188.

4. Gurlov V. (2016) "Forms and types of public unions and associations" [Online], available at: https://pravdop. com/ua/publications/kommentariizakonodatelstva/formi-i-vidi-obshestvennih-obedineniy (Accessed 11 Jen 2019)

5. Grudnyczka S. M., Rucynska, T. P. (2014), "Problems of development of the Ukrainian legislation on Public Associations: economic and legal analysis”, Forum prava, [Online], vol. 4, pp. 99-106, available at: http: nbuv.gov. ua/j-pdf/FP_index.htm_2014_4_20. pdf (Accessed 12 Jen 2019)

6. Rucynska T. P. (2015), "Improvement of legislation on Public Associations in the light of Eurointegration: economic and legal analysis", Naukovyj visnyk Uzhgorodskogo nacionalnogo universytetu. № 31, vol. 2, p. 60-64.

7. Tytova O. V. (2016), "Some aspects of the status of public associations that directly engage in entrepreneurial activity”, Forum prava, [Online], vol. 3, p. 250-254, available at: http: nbuv.gov. 
ua/j-pdf/FP_index. htm_2016_3_46. pdf (Accessed 10 Jen 2019)

8. The Verkhovna Rada of Ukraine (2017), The Law of Ukraine "On Public Associations" available at: https:// zakon.rada.gov.ua/laws/show/457217 (Accessed 10 Jen 2019).

9. Kyslov D. V., Romanenko E. A., Chaplaj $Y$. V. (2018), Marketyngovie kommunykacy $\mathrm{v}$ publychnom admynystryro- vanyy [Marketing Communications in Public Administration], LAP Lambert Academic Publishing, Germany.

10. "For Children with Love" (2018), available at: https://youtu.be/4aWhFMEjgQ (Accessed 12 Jen 2019)

11. "The Day of Well-being" (2018), available at: https://www.youtube.com/ watch? $\mathrm{v}=$ NvbIDlbioe $4 \& \mathrm{t}=296 \mathrm{~s} \quad($ Accessed 12 Jen 2019). 